\title{
CONTEXTUALISING SHORT-TERMISM: DOES THE CORPORATE LEGAL LANDSCAPE FACILITATE MANAGERIAL MYOPIA?
}

\author{
Andrea Bowdren*
}

\begin{abstract}
Despite the media attention lavished on short-termism, the UK perspective has not enjoyed any sustained examination of the sort Professor Mark Roe has undertaken in the US. The short-termist view provides that substantial weight is placed on current profits, leading to companies being managed according to these same short-term horizons, through transmission mechanisms from market to boardroom. This paper analyses whether short-termism in listed companies should affect corporate lawmaking in the UK. It examines market behaviour and the legal landscape, and the extent to which they dissuade or stimulate the corporate search for instant gratification. This paper assesses hostile takeovers, executive remuneration and shareholder activism as potential transmission mechanisms for short-termism. It finds that the first two are particularly effective mechanisms, while the third is circumscribed by the costs of collective action and rational apathy. The conclusion is that short-termism in listed companies should affect regulatory and legislative proposals in the UK. Breaking transmission mechanisms is crucial to prevent short-termism in corporate decision-making. Regulatory proposals are therefore suggested, endorsing Main's Career Shares and reform of the composition of remuneration committees.
\end{abstract}

\section{A. INTRODUCTION}

The markets are 'now all about speed.' ${ }^{1}$ While high-frequency trading has dominated headlines, a short-term focus is perceived to pervade every aspect of the market. Illustrating this, the average duration that equity is held in the UK has fallen from around five years in the 1960s, to seven and a half months in 2007, and to about eight months in $2010 .^{2}$ Although there is no precise definition, ${ }^{3}$ short-termism may be described as the 'excessive focus' of executive directors, ${ }^{4}$ asset managers, investors, and analysts on immediate results, and 'a lack of attention

\footnotetext{
* LLM Corporate and Securities Law (London School of Economics and Political Science); BCL International (University College Cork). The author is grateful to Professor David Kershaw for guidance provided during the writing of the dissertation on which this article is based, and to this journal's editors for their valuable comments.

${ }^{1}$ Michael Lewis, 'The Wolf Hunters of Wall Street: An Adaptation From "Flash Boys: A Wall Street Revolt," by Michael Lewis' NYT Magazine (New York, 31 March 2014)

<http://www.nytimes.com/2014/04/06/magazine/flash-boys-michael-lewis.html?_r=0> accessed 23 January 2016.

2 Andrew Haldane, 'Patience and Finance' (Speech at Oxford China Business Forum, Beijing, 2 September 2010) 16 〈http://www.bankofengland.co.uk/archive/Documents/historicpubs/speeches/2010/speech445.pdf> accessed 23 January 2016; Paul Woolley, 'Why are Financial Markets So Inefficient and Exploitative - and a Suggested Remedy' in Adair Turner and others (eds.) The Future of Finance: The LSE Report (London School of Economics and Political Science 2010) 133.

${ }^{3}$ Claire L Marston and Barrie M Craven, 'A Survey of Corporate Perceptions of Short-Termism Among Analysts and Fund Managers’ (1998) 4 Eur J Fin 233, 234.

${ }^{4}$ References to executives, directors, and managers all concern executive members of the decision-making body of listed companies in the UK.
} 


\section{Contextualising Short-Termism: Does the Corporate Legal Landscape Facilitate Managerial Myopia?}

to the strategy, fundamentals, and conventional approaches to long-term value creation. ${ }^{5}$ It has been characterised as a propensity to under-invest in product development and employee expertise, and as hyperactive behaviour by directors whose corporate strategy focuses on restructuring at the expense of sustainable growth. ${ }^{6}$ The core short-termist argument posits that securities traders hold their stock for short periods, during which they seek strong corporate results so they can sell profitably. ${ }^{7}$ This search is facilitated by the relative simplicity and accessibility of quarterly earnings or interim management reports. ${ }^{8}$ As a result of this shortterm orientation, too much weight is placed on current profits, and this causes companies to be managed according to the same short-term horizons as their investors. ${ }^{9}$

Despite the media attention lavished on short-termism, ${ }^{10}$ it remains poorly understood. There is no consensus on its status as a problem worthy of intervention by corporate lawmakers. $\mathrm{T}$ Boone Pickens took a sceptical view of short-termism in the $1980 \mathrm{~s}^{11}$ and more recently Professor Mark Roe concluded that debilities in the standard short-termist view render it untenable and unworthy of consideration by the legislature. ${ }^{12}$ Conversely, several institutes posit that short-termism can undermine the market's credibility and lead to value-destruction. ${ }^{13}$ Other commentators find themselves between the two aforementioned views, considering short-termism to be "more narrowly focused and of lesser importance than its supporters claim. $^{14}$

\footnotetext{
${ }^{5}$ CFA Center For Financial Integrity and Business Roundtable Institute For Corporate Ethics, 'Breaking The Short-Term Cycle: Discussion and Recommendations on How Corporate Leaders, Asset Managers, Investors and Analysts Can Refocus on Long-Term Value' (2006) 3

$<$ http://www.cfapubs.org/doi/pdf/10.2469/ccb.v2006.n1.4194> accessed 17 August 2016.

${ }^{6}$ John Kay, 'The Kay Review of UK Equity Markets and Long-Term Decision Making' Final Report (BIS 2012) 10.

${ }^{7}$ Mark Roe, 'Corporate Short-Termism - In the Boardroom and in the Courtroom' (2013) 68 Business Lawyer 977, 981, 985; Alfred Rappaport, 'The Economics of Short-Term Performance Obsession' (2005) 61(3) Fin. Analyst J 65, 66.

${ }^{8}$ For academic modelling see Jeremy C Stein, 'Efficient Capital Markets, Inefficient Firms: A Model of Myopic Corporate Behavior,' (1989) 104 Q J Economics 655.

${ }^{9}$ Roe (n 7) 985-986.

${ }^{10}$ John Chapman, 'Time to Tackle UK Short-Termism' Financial Times (London, 27 May 2012); Bill George 'Activists Seek Short-Term Gain, Not Long-Term Value' New York Times (New York, 26 August 2013); Roger L Martin, 'Yes, Short-Termism Really is a Problem' Harvard Business Review (8 October 2015); Joe Nocera, 'What is Business Waiting for?' New York Times (New York, 16 August 2011) A21; Mark J Roe, 'The Imaginary Problem of Corporate Short-Termism' Wall Street Journal (New York, 17 August 2015); Judith Samuelson and Lynn Stout, 'Are Executives Paid Too Much?' Wall Street Journal (New York, 26 February 2009) A13; James Surowiecki, 'The Short-Termism Myth' The New Yorker (New York, 24 August 2015).

${ }^{11}$ T. Boone Pickens, 'Professions of a short-termer' (1986) 64(3) Harvard Bus Rev 75, 76 where it was said '[i]ncreasing acceptance of the short-term theory has freed executives to scorn any shareholders they choose to identify as short-termers.'

${ }^{12}$ Roe (n 7) 981.

${ }^{13}$ Aspen Institute Business and Society Program, 'Overcoming Short-termism: A call for a more responsible approach to investment and business management' (2009) 2; CFA (n 5 ) 3.

${ }^{14}$ Marston and Craven (n 3) 234.
} 
Although short-termism has had an undeniable grip on the corporate legal imagination, ${ }^{15}$ it has not benefited from a sustained examination from the UK perspective. This paper examines behaviour in UK financial markets, the corporate legal landscape in which the markets function, and the extent to which they dissuade or stimulate the corporate search for instant gratification. ${ }^{16}$ It looks at whether the available evidence is reflective of a harmful short term focus, which requires action by legislators and regulators. For the short-termist argument to have traction, trading structures require a 'transmission mechanism' into a company to affect corporate time horizons, as otherwise directors could be 'free to decide on corporate investments and time horizons.' ${ }^{17}$ Roe considered hostile takeovers as a transmission mechanism in the 1980s and that, currently, shareholder activism and executive remuneration could fulfil this role. ${ }^{18}$ Each of these transmission mechanisms will be examined from a UK perspective.

This paper also analyses whether perceptions of short-termism alone can lead to managerial myopia, ${ }^{19}$ where managers take actions to increase current earnings at the expense of long-term value, by virtue of their belief that short-termism afflicts the market. Turning to potential regulatory responses, the argument in favour of increasing board autonomy will be scrutinised and other regulatory recommendations will be briefly addressed. The author, in rejecting Roe's assertion that short-termism should not affect corporate law making, ${ }^{20}$ concludes that there are effective mechanisms transmitting short-termism in the market to corporate decision-making to render the issue worthy of legislative and regulatory attention.

\section{B. SHORT-TERMISM FROM LEGAL AND EVIDENTIAL PERSPECTIVES}

\section{The Corporate Legal Landscape}

Shareholders dominate UK company law. ${ }^{21}$ Section 172 of the Companies Act 2006 provides that a director must act in a way he considers 'most likely to promote the success of the company for the benefit of its members as a whole.' The 'preferable analysis' is that it requires directors to have regard to the long-term interests of shareholders and, in doing so, directors

\footnotetext{
15 ibid 979. Professor Mark Roe performed such an examination from the US' perspective in The Business Lawyer. Roe's analysis and terminology will be utilised throughout.

16 Kay Review (n 6) 14.

17 ibid

18 ibid

${ }^{19}$ Istemi Demirag, 'Boards of Directors' short-term perceptions and evidence of managerial short-termism in the UK' (1998) 4(3) Eur J of Finance 195.

${ }^{20}$ Roe (n 7) 978.

${ }^{21}$ Louise Gullifer and Jennifer Payne, Corporate Finance Law: Principles and Policy (Hart Publishing 2011$) 63$.
} 
may 'take account of other stakeholder groups [...] to determine what best ensures the longterm growth of the company.' 22 This is known as the 'enlightened shareholder value' approach. ${ }^{23}$ While UK company law is tempered by this requirement to have regard to other constituencies, it is still dominated by shareholder primacy. Maximising profit for shareholders is the most fundamental interpretation of benefiting the members of the company as a whole. UK takeover regulation developed separately to the regulation of the securities markets ${ }^{24}$ and corporate law. Representatives of merchant banks, institutional investors and the London Stock Exchange prepared the first set of rules, the Notes of Amalgamation of British Businesses, in 1959. ${ }^{25}$ Consequently, the focus was not on securing the position of directors, but rather safeguarding shareholder interests. ${ }^{26}$ The first City Code on Takeovers and Mergers (the Code) superseded the Notes in 1968, and the self-regulatory regime is still very much in evidence in the UK. '[T] he City of London prided itself upon being a village community, [...] which could regulate itself by pressure of professional opinion. ${ }^{27}$ The Panel on Takeovers and Mergers (the Panel) administers the Code, is primarily staffed by secondments from City firms, ${ }^{28}$ and is 'untrammeled by the procedural and precedential niceties of the courtroom.' ${ }^{29}$ The influence of shareholder-friendly groups in the development of the system ${ }^{30}$ resulted in a prohibition on board frustration of bids. ${ }^{31}$

As a result, UK law facilitates the City of London's operations, and shareholders are the dominant force in both UK corporate law and UK takeover regulation. In UK corporate law, although directors may look to other stakeholder interests, their decisions must benefit the shareholders as a whole. UK takeover regulation also preserves shareholder interests and, unlike in the US, no action may be taken by a board to halt a takeover bid without contemporaneous shareholder approval. The powerful position of shareholders impacts upon the analysis in this paper and circumscribes what reform can realistically be achieved.

\footnotetext{
22 ibid.

${ }^{23}$ Company Law Review Steering Group, Modern Company Law for a Competitive Economy: The Strategic Framework (DTI 1999) 37.

${ }^{24}$ Gullifer and Payne (n 21) 568.

25 Issuing Houses Association, Notes on Amalgamation of British Businesses (1959).

${ }^{26}$ Gullifer and Payne (n 21) 568; John Armour and David Skeel, 'Who Writes the Rules for Hostile Takeovers, and Why? The Peculiar Divergence of US and UK Takeover Regulation' (2007) 95 Georgetown L J 1727, 1730.

${ }^{27} R v$ Panel on Takeovers and Mergers, ex parte Datafin, [1987] QB 815, 835.

${ }^{28}$ Andrew Johnston, The City Takeover Code (OUP 1980), 127.

${ }^{29}$ Armour and Skeel (n 26) 1728.

30 ibid 1730, 1764-76.

${ }^{31}$ Panel on Takeovers and Mergers, 'The City Code on Takeovers and Mergers' (11th edn 2013) Rule 21.
} 


\section{Evidence of Short-Termism}

a) Testing for Short-Termism

The significant difficulty in testing for short-termism is illustrated in the dialogue between Miles, and Satchell and Damant in the 1990s. Miles' findings prompted him to ask detractors of the short-termist argument why 'longer-term cash flows appear to be discounted at much higher rates than shorter-term flows. ${ }^{32}$ As Miles' results were based on analysing 477 companies that reported annually from 1977 to 1990, Satchell and Damant suggested a survivorship bias afflicted Miles' study. ${ }^{33}$ Survivorship bias is the tendency for failed companies to be excluded from studies, causing distorted results, as only companies successful enough to survive until the end of the period are included. Therefore, the market may not be undervaluing future cash flows but risk-discounting them for the possibility of company failure. As it was 'not obvious how one could achieve' ${ }^{34}$ a satisfactory test, Satchell and Damant did not suggest an alternative. Similarly, Demirag posited it is 'probably impossible' ${ }^{35}$ to evidence the existence of short-termism.

Nonetheless, it is often observed that markets underestimate long-term corporate cash flows. ${ }^{36}$ Directors regularly lament shareholder pressure to produce consistent short-term results. ${ }^{37} \mathrm{~A}$ recent review of the UK equity markets concluded that short-termism is a problem, ${ }^{38}$ identifying the principal causes as the decline of trust and misalignment of incentives throughout the investment chain. Similarly, Sir Roger Carr, former Chairman of Cadbury plc, attributed short-termism to a change in corporate ownership profiles and fund management performance pressures, which focus on immediate gains rather than long-term wealth creation. ${ }^{39}$ Without a clear, accepted test for short-termism or agreement on the principal causes, this paper examines market characteristics such as decreasing holding periods, and the knowledge and nature of investors, to see if the market displays or favours shorttermism.

\footnotetext{
${ }^{32}$ David Miles, 'Testing for short-termism in the UK stock market' (1993) 103(421) Economic J 1379, 1394.

${ }^{33}$ Stephen E Satchell and David C Damant, 'Testing for short-termism in the UK stock market: a comment' (1995) 105(428) Economic J 1218, 1218.

34 ibid 1223.

35 Istemi Demirag, 'Assessing short-term perceptions of group finance directors of UK companies' (1995) 27 British Accounting Rev 247, 277.

${ }^{36}$ Angela Black and Patricia Fraser, 'Stock Market Short-Termism - An Internal Perspective' (2002) 12 J of Multinational Financial Management 135; Roe (n 9) 986.

${ }^{37}$ Roe (n 9) 987; John Graham and others, 'The Economic Implications of Corporate Financial Reporting' (2005) $40 \mathrm{~J}$ of Accounting and Economics 3; Marston (n 3) 236.

${ }^{38}$ Kay Review (n 6) 9.

${ }^{39}$ Roger Carr, Speech to Said Business School, (Oxford, 9 February 2010) 2

<http://www.efinancialnews.com/share/media/downloads/2010/02/1056530392.pdf> accessed 23 January 2016.
} 


\section{b) Decreasing Holding Periods}

Short-termism may be observed in the shortening of investment horizons over the last two decades. ${ }^{40}$ The average holding period in professionally managed funds is less than a year. ${ }^{41} \mathrm{In}$ 2010, turnover on the major equity exchanges was running at 150 percent per annum of aggregate market capitalisation which implies average holding periods of eight months: ${ }^{42} \mathrm{a}$ decrease from around five years in the $1960 \mathrm{~s} .{ }^{43}$ The increase in derivatives trading, the majority of which mature in less than a year, is also symptomatic of shortening horizons. ${ }^{44}$ On the significance of holding periods, Professor Alfred Rappaport posits:

[t] he shorter the holding period, the more the beliefs of others rather than long-term fundamentals become central to investment decisions. High turnover thus sets the stage for short-term earnings-based decision making or momentum-motivated trading. ${ }^{45}$

Momentum-based strategies and investment on the basis of estimated future earning and dividends have been compared to the hare and the tortoise. ${ }^{46}$ The hare has 'bursts of success' while the 'tortoise plods steadily on concentrating on real value and wins the race in the end. ${ }^{47}$ Momentum trading and resulting distortions are seen as 'part and parcel' ${ }^{48}$ of the trend towards increasing short-termism and high trading volumes, with emphasis being put on short-term price changes.

A commonly stated justification for increased trading is raising liquidity. However, in an imperfect market, ${ }^{49}$ this increased ability to buy and sell may come at a cost, potentially bringing increased volatility and short-termism with it. Costs associated with increased trading for long-term investors include active management fees and associated trading costs, which can erode the value of funds. ${ }^{50}$ Further, there is scepticism whether the liquidity benefits claimed would exist in the periods of acute market uncertainty when they might be required. ${ }^{51}$ Hence, the main advantage identified with a higher turnover of shares in companies may not

\footnotetext{
${ }^{40}$ Woolley (n 2) 133.

${ }^{41}$ Rappaport, (n 7) 66.

42 Woolley (n 2) 133.

${ }^{43}$ Haldane (n 2) 16.

${ }^{44}$ Woolley (n 2) 133.

${ }^{45}$ Rappaport (n 7) 65-66.

46 Woolley (n 2) 136.

47 ibid 137.

48 ibid 133.

${ }^{49}$ Kay Review (n 6) 26, 35, 39; Financial Services Authority, 'The Turner Review: A Regulatory Response to the Global Banking Crisis' (FSA 2009) 40-42.

${ }^{50}$ Woolley (n 2) 134; CFA (n 5)11.

${ }^{51}$ Kay Review (n 6) 38.
} 
even persist in the situations where it would be needed most, highlighting the problematic nature of increased trading.

Shortening horizons cannot be addressed without mentioning high-frequency trading (HFT). ${ }^{52}$ The 'lexicon of financial markets is dominated by talk of [...] [HFT]. It is not just talk. ${ }^{53}$ In HFT, time horizons are measured in fractions of a second, with activities conducted by computers using programmed algorithms, since the speed required is far beyond the capacity of human beings. ${ }^{54}$ From 2005 to 2011, HFT increased from a tiny proportion to over 35 percent of the European equity market. ${ }^{55}$ In the UK, about two thirds of share turnover is accounted for by hedge funds and high-frequency traders. ${ }^{56}$

HFT is not in itself evidence of 'damaging short-term behaviour in the decisions that matter to the British economy. ${ }^{, 57}$ It is too fast to impact upon the thought processes or strategy of market participants and too speedy to transmit short-term incentives to management. HFT is not either in itself a major contributor to short-termist behaviour but an aspect of a broader trend favouring trading over trust relationships. ${ }^{58}$ Roe acknowledges that decreases in holding periods, otherwise known as a high churn rate, ${ }^{59}$ would not render short-termism a problem requiring legislative or regulatory remedy unless a transmission mechanism brings these decreased trading horizons within management's considerations in the corporate decisionmaking process. ${ }^{60}$

\section{c) Knowledge and Nature of Investors}

This section assesses whether the knowledge and nature of investors constitute market characteristics from which short-termism may be observed. Shareholders focus on short-term financial accounts when they lack the knowledge to distinguish between losses arising from long-term expenditure and managerial incompetence. Turning to the nature of investors, where

\footnotetext{
${ }^{52}$ High-frequency trading is a type of computerised trading using complex, proprietary algorithms to execute orders at very high speeds based on market conditions.

${ }^{53}$ Andrew Haldane, 'The Race to Zero' Speech at International Economic Association Sixteenth World Congress (Beijing, 8 July 2011) 4

<http://www.bankofengland.co.uk/publications/Documents/speeches/2011/speech509.pdf > accessed 23 January 2016.

${ }^{54}$ Kay Review (n 6) 14.

55 Andrew Haldane (n 53) 4.

${ }^{56}$ House of Commons Business, Innovation and Skills Committee, 'The Kay Review Submissions (Version 3, 26 March 2013),' 14

〈http://www.publications.parliament.uk/pa/cm201213/cmselect/cmbis/writev/kay/kay.pdf> accessed 17 August 2016.

${ }^{57}$ Kay Review (n 6) 14.

58 ibid 39.

${ }^{59}$ In this context, churn rate refers to the percentage of shareholders who dispose of their shares within a given time period.

${ }^{60}$ Roe (n 9) 999.
} 


\section{Contextualising Short-Termism: Does the Corporate Legal Landscape Facilitate Managerial Myopia?}

an intermediary such as a fund manager manages shareholdings, the fund managers' concerns are transferred to the market. If these concerns relate to their own short-term relative performance, there will be increasing attention on market trends rather than on long-term value creation.

It is difficult for shareholders to deduce whether a company is making sound long-term investments, which may lead to short-term losses, or if short-term losses are caused by managerial incompetence. ${ }^{61}$ This informational asymmetry between shareholders and managers may lead to shareholder reliance on current results, as it is easy to see whether the stock price went up on any particular day. ${ }^{62}$ To an extent, this lack of investor knowledge binds investor confidence to the next set of financial results, leading to demands to increase share price and placing pressure on the board to do so.

The nature of shareholders also plays a role, where a change in ownership profiles in the UK has consisted of increased fragmentation. Historically, institutional investors occupied a high proportion of the UK equity markets. ${ }^{63}$ In 2012 pension funds and insurance companies held only 10.9 percent, ${ }^{64}$ with non-UK holders accounting for over 50 percent, ${ }^{65}$ and individual shareholders holding 10.7 percent. ${ }^{66}$ Thus, shareholders who in the past may have engaged with each other and then approached the board asking for an explanation for certain losses, are discouraged from doing so as a result of the dispersion of shares among non-UK holders and individual shareholders. These issues are known as collective action problems. ${ }^{67}$

The prevalence of intermediation ${ }^{68}$ is another aspect of the nature of investors relevant for evidencing short-termism. Intermediation has led to a decline of the role of individual shareholders, ${ }^{69}$ with asset managers now considered the 'dominant players in the investment chain. ${ }^{70}$ Thus, asset managers' considerations and concerns contribute to market behaviour.

\footnotetext{
${ }^{61}$ Samuelson and Stout (n 10) A13.

62 ibid.

63 Armour and Skeel (n 26) 1766.

${ }^{64}$ Office for National Statistics, 'Ownership of UK Quoted Shares 2012' Statistical Bulletin (2013) 1.

65 ibid 12.

66 ibid 18.

${ }^{67}$ David Kershaw, Company Law in Context (2nd edn, OUP 2012) 175. 'Collective action' refers to the behavior of a group working to achieve a common goal. As shareholdings are increasingly dispersed, and shareholders are separated in terms of location with non-UK holders accounting for a majority of the UK equity market, the likelihood of groups of shareholders forming to reach a goal is unlikely as the costs of such activity would be likely to outweigh any potential result.

${ }^{68}$ In this context, intermediation refers to a situation where third parties act as a middleman between investors and companies, such as mutual fund managers who actively manage capital pooled by investors and make decisions about which shares to purchase on the investors' behalf.

${ }^{69}$ Kay Review (n 6) 30.

70 ibid 11.
} 
Critical time horizons for asset managers are the timescale within which an asset manager's performance is judged (the performance horizon) and the speed at which the prices of shares revert to their fundamental value (the value discovery horizon). The shorter the performance horizon is relative to the value discovery horizon, the greater the incentive for managers to focus on the behaviour of other market participants rather than fundamental value, ${ }^{71}$ ie the higher the likelihood of short-termism.

The design of asset managers' contracts also influences their behaviour and management of investors' funds, with fee structures based on short-term performance that encourage short horizons and momentum trading. ${ }^{72}$ Before hiring asset managers, investors review their "performance relative to index benchmarks or [...] relative to other asset managers. ${ }^{73}$ Consequently, the concern of asset managers is short-term relative performance and this triggers a "vicious circle ${ }^{74}$ of increasing attention to market trends and diminishing attention to fundamental value, in other words, short-termism. This concern for short-term performance was recently illustrated by the behaviour of US funds reducing their exposure in UK markets amid fears the UK would vote to leave the EU. ${ }^{75}$ Bank of America Merrill Lynch's Global Fund Manager Survey published in May 2016 concluded that the Brexit vote was seen as the biggest 'tail risk' facing fund managers and stated that UK equity allocation had plunged to its lowest level since $2008 .{ }^{76}$ Therefore, a short-term focus can present itself as a result of the knowledge and nature of investors.

\section{Conceptual and Factual Issues with the Short-Termist Argument}

Roe identified substantial conceptual and factual debilities afflicting the short-termist argument, which may justify the view that courts and corporate lawmakers should be reluctant in allowing short-termism to join the considerations that go into lawmaking. ${ }^{77}$ Certain select debilities will be assessed from a UK perspective, to consider if they offset the evidence in favour of increasing short-termism, altering the weight that ought to be afforded to the argument in policy discussions.

\footnotetext{
71 ibid 40.

72 Woolley (n 2) 133.

${ }^{73}$ Kay Review (n 6) 40.

74 ibid.

${ }^{75}$ David Oakley, Stephen Foley and Michael Pooler, 'US funds cut exposure to UK equities amid Brexit fears' Financial Times (London, June 21 2016).

${ }^{76}$ Michael Hartnett, Brian Leung CFA, 'Global Fund Manager Survey - if you go down to the woods today...,' Bank of America Merrill Lynch, 17 May 2016.

${ }^{77}$ Roe (n 7) 979-981.
} 


\section{a) The UK Economy}

Several features of the UK economy may incentivise or facilitate long-term profitability, thereby counterbalancing short-termism to the extent that short-termism ought not to be a consideration for corporate lawmakers. This section assesses whether the presence of venture capital markets and private equity markets sufficiently mitigates short-term tendencies in the public market, such that short-termism is not a systemic issue and, therefore, should not be remedied by the legislature as though it is. Even if these features are insufficient to negate the corresponding short-termist features of the market, such as decreasing holding periods or the behaviour of funds managers, they provide alternatives to public ownership that could result in short-termism being problematic for certain companies, but not necessarily for the economy as a whole. ${ }^{78}$

The presence of venture capital markets, private equity markets and privately held firms may serve to mitigate short-term tendencies in the public market, meaning short-termism is not a systemic issue. Private equity encompasses a number of different types of transactions, but has come to be most closely associated with buy outs, ${ }^{79}$ where private equity firms buy majority control of an existing or mature firm, or a publicly owned company which is then taken private. Private equity holders tend to 'reorient its business model towards the longer term. ${ }^{80}$ The usual hold period by a private equity fund is three to five years. ${ }^{81}$ If a company is overly focused on short-term financial results, therefore, marketplace incentives would be to move the firm into private equity's hands, where the horizons are longer. ${ }^{82}$ Though private equity is far from perfect, the presence of alternatives highlights that there are offsets to short-termism, overlooked in many analyses. However, the presence of venture capital markets and private equity markets is not sufficient to counter all negative consequences of short-termism and does not alter the weight that should be afforded to the short-termist argument in policy discussions.

b) Long-Termism in the Markets

The short-termist view neglects the possibility that excessive value can be attributed to certain sectors and companies, such that the markets sometimes seem to be excessively long-term in their horizons. Market 'bubbles' illustrate this stock market long-termism, where excessive, intermittent high valuations are accorded to one sector or another of the financial market. ${ }^{83}$ The

\footnotetext{
78 ibid 993.

${ }^{79}$ Gullifer and Payne (n 21) 654-655.

${ }^{80}$ Roe (n 7) 988.

${ }^{81}$ Gullifer and Payne (n 21) 686.

82 ibid.

${ }^{83}$ Roe (n 7) 995.
} 
millennium opened with the technology stock bubble that caused large-scale misallocation of capital. ${ }^{84}$ Technology stocks received an initial boost from fanciful expectations of future profits from scientific advances, ${ }^{85}$ funds invested in unglamorous 'value' sectors languished, prompting investors to switch funds to the newly successful growth managers, and value managers themselves began switching from value to growth to retain their jobs. ${ }^{86}$ 'Once momentum becomes embedded in markets, agents then logically respond by adopting strategies that are likely to reinforce the trends. ${ }^{87}$

In such instances, the market is giving excessive weight to the long-term as companies are accorded high valuations, without having demonstrated abilities in the immediate term to generate profits. Overvaluation is indicative of an unrealistic belief that the share price can continue to rise indefinitely or for a long period. While this demonstrates that both excessive short and long-term behaviour can be found in the markets, excessive long-termism is limited to certain sectors, in which a lack of evidence of profit-making abilities is excused for whatever reason. In contrast, short-termism pervades the market generally, as evidenced in market characteristics such as decreasing holding periods, knowledge of investors, and nature of investors. As a result, the relatively rare market occurrence of something like the technology stock 'bubble' does not alter the weight that should be afforded to the short-termist argument in corporate law-making debates.

c) Short-Termism within Companies

Capital markets are just 'one piece of the jigsaw' 98 and corporate law or regulations facilitating the transmission of any short-termism present in the market into the boardroom must be assessed. Mechanisms and structures within a company are important sources of short-term distortions. ${ }^{89}$ These include fee structures and tenure, which have their origins in managerial labour markets, not stock markets. ${ }^{90}$ Companies can design longer-term remuneration contracts to mitigate any short-term features they see as potentially harmful. ${ }^{91}$ By examining transmission mechanisms, the extent to which short-termism is endogenous to the company

\footnotetext{
${ }^{84}$ Woolley (n 2) 121.

${ }^{85}$ Eli Ofek and Matthew Richardson, 'Dot.Com Mania: The Rise and Fall of Internet Stock Prices' (2003) 58(3)

$\mathrm{J}$ of Finance 1113.

86 Woolley (n 2) 126.

87 ibid.

${ }^{88}$ House of Commons Business, Innovation and Skills Committee (n 56) 16.

${ }^{89}$ Roe (n 7) 980.

90 Tim Campbell and Anthony Marino, 'Myopic Investment Decisions and Competitive Labor Markets' (1994) 35 Intl Econ Rev 855, 858.

${ }^{91}$ Roe (n 7) 998.
} 
will be clearer. Each of the three transmission mechanisms considered by Roe - hostile takeovers, shareholder activism, and executive remuneration ${ }^{92}$ - will be analysed.

\section{TRANSMISSION MECHANISMS FROM MARKET TO BOARDROOM}

\section{Takeovers}

a) The Market for Corporate Control

The market for corporate control ${ }^{93}$ sees hostile takeovers as a key mechanism for aligning managers' interests with those of shareholders, with the threat of a takeover pressurising the board to generate profit. ${ }^{94}$ One premise of the market for corporate control is that there is 'a high positive correlation between corporate managerial efficiency and the market price of shares of that company. ${ }^{95}$ If the managers' behaviour lowers the price of a company's shares, market participants will identify an opportunity to take over the company for less than it would be worth under superior management. ${ }^{96}$

Where there is a wide separation between share ownership and control, directors may engage in opportunistic behaviour. ${ }^{97}$ This includes attempts to extract private benefits from the company or shirking duties ${ }^{98}$ and leads to agency costs. ${ }^{99}$ The 'crescendo' of the distinction between the corporate entity and its shareholders is reached in the context of a takeover. ${ }^{100}$ The distinction, combined with a free market, means ownership can change over the management's head. ${ }^{101}$ Therefore, in order to avoid issues of short-termism, boards must keep shareholders with increasingly short holding periods satisfied, ie unwilling to sell their shares to a predator. Unsurprisingly, managerial focus will be on maintaining and maximising share price. Yet, companies seek to maximise current earning at the expense of sound balance sheets, capital

\footnotetext{
92 Roe (n 7) 985.

93 The 'market for corporate control' refers to how underperforming companies become attractive targets for hostile takeovers. Poor performance can be a reflection of problems with internal governance, which encourages potential acquirers to purchase a substantial number of the company's shares to take control of the board and replace the directors. The threat of a takeover pressurises the board to generate profit, aligning its interests with shareholders.

${ }^{94}$ Henry G Manne, 'Mergers and the Market for Corporate Control' (1965) 73 J Pol Econ 110.

95 ibid 112.

96 ibid 113.

${ }^{97}$ Stephen M Bainbridge, 'The Business Judgment Rule as Abstention Doctrine' (2004) 57 Vanderbilt L Rev 83, 107.

98 Michael Dooley, 'Two Models of Corporate Governance' (1992) 47 Business Lawyer 461, 465.

99 Paul Rose, 'Common Agency and the Public Corporation' (2010) 63 Vanderbilt L Rev 1355, 1361.

100 Alan Paul, 'Corporate Governance in the Context of Takeovers of UK Public Companies' in DD Prentice and PRJ Holland (eds), Contemporary Issues in Corporate Governance (OUP 1993) 135.

101 ibid.
} 
investment, research and development (R\&D), and job growth. ${ }^{102}$ Martin Lipton offered shorttermism as a reason why hostile takeovers needed to be stopped, asserting the issue as '[w]hether the long-term interests of the nation's corporate system and economy should be jeopardized in order to benefit speculators interested $[\ldots]$ only in a quick profit $[\ldots]$ ? $^{103}$

b) Prohibition of Takeover Defences

The extent to which hostile takeovers may align the interests of shareholders and managers is determined by the legal and regulatory landscape, particularly whether executives can employ defences such as poison pills, ${ }^{104}$ without shareholder approval. The Code prohibits 'management from employing any defensive tactics that would have the effect of frustrating an actual or anticipated bid ${ }^{\prime 105}$ unless there is contemporaneous shareholder approval. Hence, UK boards cannot, as is prevalent in the US, prevent a takeover and preserve their jobs by putting a specially designed shareholder rights plan in place to render the company's shares less attractive to potential acquirers, unless the shareholders themselves have approved this action.

In the UK, the target board issues an opinion on an offer made to buy up a company's shares. ${ }^{106}$ The Code does not limit the factors the board may take into account, nor does it require the board to consider the offer price as the determining factor in their opinion. ${ }^{107}$ However, boards' opinions are likely to pivot on the financial terms of the offer. AstraZeneca's recent board rejection is an example of this, stating 'the financial and other terms [...] are inadequate, [and] substantially undervalue AstraZeneca. ${ }^{108}$ The Code and UK corporate law are therefore 'clear manifestation[s] of the [...] philosophy that boards ha[ve] a duty to prioritise the short-term financial interests of shareholders.' ${ }^{109}$

\footnotetext{
${ }^{102}$ Martin Lipton, 'Empiricism and Experience; Activism and Short-Termism; the Real World of Business' (Harvard Law School Forum on Corporate Governance and Financial Regulation, 28 October 2013) $<$ https://blogs.law.harvard.edu/corpgov/2013/10/28/empiricism-and-experience-activism-and-short-termism-thereal-world-of-business/> accessed 23 January 2016.

${ }^{103}$ Martin Lipton, 'Takeover Bids in the Target's Boardroom' (1979) 35 Business Lawyer 101, 104; Roe (n 9) 979.

${ }^{104}$ A 'poison pill' refers to a shareholder rights plan used to prevent hostile takeovers, by causing company shares to become unattractive to potential acquirers. For example, one kind of poison pill permits shareholders except for the acquirer to buy additional shares at a discount, hence increasing the number of shares the acquirer will have to buy.

${ }^{105}$ Armour and Skeel (n 26) 1728; Code (n 31) Rule 21.

${ }^{106}$ Code (n 31) Rule 25.2.

107 ibid Rule 25.2, Note 1.

${ }^{108}$ AstraZeneca, 'AstraZeneca Board rejects Pfizer proposal' (2 May 2014)

$\langle$ http://www.astrazeneca.com/Media/Press-releases/Article/20140502--astrazeneca-board-rejects-pfizerproposal> accessed 23 January 2016.

${ }^{109}$ Simon Deakin, 'The Coming Transformation of Shareholder Value' (2005) 13 Corp Governance: An Intl Rev 11,14 .
} 
In recent years, concern has increased about the vulnerability of UK companies to takeovers. The UK is 'one of a few major economies in which the hostile bid is free to flourish,' with the company's fate left 'in the hands of the shareholders,' a group which may change throughout the course of a bid. ${ }^{110}$ For instance, public opprobrium followed Kraft's unsolicited acquisition of Cadbury in 2010, with Sir Roger Carr complaining that the protracted takeover battle led to short-term investors replacing long-term institutional investors. He ultimately concluded it was too easy to take over UK companies. ${ }^{111}$

The Panel responded to this concern ${ }^{112}$ by amending the Code in $2011^{113}$ to increase protection against protracted 'virtual bid' periods, where a potential offeror announces that it is considering making an offer but does not commit to doing so. ${ }^{114}$ A further amendment improved the quality of disclosure of the offeror's intentions regarding the target and its employees, ${ }^{115}$ though the generality of many disclosures disappointed the Code Committee. ${ }^{116}$ These amendments lead potential bidders to be more circumspect when approaching potential targets, but rather than solving the problem, they delay it for a six month period. ${ }^{117}$ This does not enable directors to take a long-term approach. The company is still vulnerable to share price volatility associated with the bid, as well as offers from other predators during these six months. Therefore, hostile takeovers are capable of influencing the time horizon for decision-making, tilting it towards the short-term.

If holding periods are decreasing, investors' focus is on securing a high share price for sale, without concern for the long-term prospects of the company. Executives of companies recently targeted or 'perceived to be susceptible,', 118 sense that predators and the market do not share their assessment of their skills and long-term value of the company. ${ }^{119}$ The resulting pressure induces managerial myopia, whereby executives focus on achieving and maintaining

\footnotetext{
110 Paul (n 100).

111 See Carr (n 39).

112 ibid 11-13; Patrick Wintour, 'Lord Heseltine expected to call for restriction of foreign takeovers,' The Guardian (London 29 October 2012) 5.

113 The Takeover Panel Code Committee, 'Review of the 2011 Amendments to the Takeover Code' (2012/8).

114 ibid 4.

115 ibid 2.

116 ibid 17.

${ }^{117}$ Code (n 31) Rule 2.8.

118 Marston and Craven (n 3) 245.

119 ibid.
} 
a high share price in the short-term to deter predators. ${ }^{120}$ This is because executives rationally fear takeovers as they 'threaten their security, jobs, and perquisites.' ${ }^{\text {, } 121}$

In the UK, therefore, hostile takeovers can still act as transmission mechanisms, as board frustration of bids without shareholder approval is prohibited. ${ }^{122}$ This leads to short-term behaviour by boards wishing to avoid being seen as potential targets. Executives' concern for retaining their position would be present without stock market short-termism, but the shortening of investment horizons intensifies pressure on executives and transmits shorttermism within the corporate decision-making body. The risk of takeovers is clearly an effective transmission mechanism of short-termism to the board.

\section{Shareholder Activism}

Shareholder activism refers to a range of actions taken by shareholder to influence corporate management and boards. ${ }^{123}$ Shareholder activists are often viewed as investors who are dissatisfied with some aspect of a company's management or operations, and try 'to change the status quo through "voice," without a change in control of the firm.' ${ }^{124}$ Actions range from threatening the sale of shares ('exit'), to asking questions at shareholder meetings and using corporate voting rights ('voice'). ${ }^{125}$ This is referred to as the 'market for corporate influence.' 126

Shareholder activism has proliferated in recent years, with activist shareholders occupying the thoughts 'and sometimes the nightmares' ${ }^{\text {' }}{ }^{127}$ of executives. In the US, activism has been described as the epitome of "short-termism as an investment style, ${ }^{128}$ with inherently negative consequences. ${ }^{129}$ Consequently, activism is perceived as a transmission mechanism, with investors using their 'voice' to express their wish for short-term returns, pressurising managers to restructure the company for short-term gains in share price. This section assesses

\footnotetext{
${ }^{120}$ Yijiang Zhao, Kung H. Chen, Yinqi Zhang, and Michael Davis, 'Takeover protection and managerial myopia: Evidence from real earnings management,' (2012) 31 J Acc Public Policy 109, 126-128.

${ }^{121}$ Marston (n 3) 245; See generally Robin Marris, The Economic Theory of Managerial Capital (Macmillan 1966).

122 Code (n 31) Rule 21.

${ }^{123}$ Stuart Gillan and Laura Starks, 'A survey of shareholder activism: Motivation and empirical evidence' (1998) 2 Contemporary Finance Digest 10.

${ }^{124}$ Stuart Gillan and Laura Starks, 'The Evolution of Shareholder Activism in the United States' (2007) 19 J of Applied Corp Finance 55, 55.

${ }^{125}$ Gillan and Starks (n 123) 11.

${ }^{126}$ Brian R Cheffins and John Armour, 'The Past, Present and Future of Shareholder Activism by Hedge Funds' (2011) 37 J Corp L 51, 58.

${ }^{127}$ Charles Nathan, 'Debunking Myths about Activist Investors' (2013) 27(3) Insights; Corporate and Securities Law Advisor 19.

128 ibid.

${ }^{129}$ George (n 10); cf Lucian Bebchuk, 'The Myth that Insulating Boards Serves Long-Term Value' (2013) 113 Columbia L Rev 1637.
} 
whether this activism promotes a short-term agenda such as an increase in price through financial engineering, thus transmitting short-termism of investors into corporate decisionmaking and governance.

a) Mechanisms for Activism

UK legislation provides mechanisms for relatively small groups of shareholders ${ }^{130}$ to require companies to present shareholder resolutions to a meeting. The articles of association cannot deprive shareholders of this. ${ }^{131}$ Shareholders also enjoy 'a non-waivable right to remove directors mid-term without cause. ${ }^{132}$ Statements of best practice such as the Corporate Governance Code and Stewardship Code promote shareholder engagement, though the efficacy of the latter has been called into question. ${ }^{133}$ Despite these facilitators, shareholder engagement is seen as an encumbrance and a cost. ${ }^{134}$ This lack of incentive for shareholders is unsurprising taking into account the market landscape, with a competitive fund management industry and increased fragmentation. ${ }^{135}$ Widely dispersed shareholding make reaching the 5 percent threshold to call a meeting and passing a proposed ordinary resolution difficult. Shareholders would need to 'join forces [...] to have a group that is powerful enough to effect change.'136 Costs incurred, referred to as 'costs of collective action,' lead investors to be rationally apathetic, hoping that someone else will make the effort. ${ }^{137}$ Therefore, as a practical matter, 'exit' is favoured over 'voice.'

\section{b) The Efficacy of Activism}

Investors theoretically have incentive and influence to engage in activism that ensures directors operate in the interests of shareholders, providing a driver of 'good' corporate governance that leads to efficiency gains and improvement in performance. ${ }^{138}$ Nonetheless, empirical studies

\footnotetext{
${ }^{130}$ Companies Act 2006, ss 303-305.

${ }^{131}$ Marco Becht and others, 'Returns to shareholder activism: evidence from a clinical study of the Hermes UK Focus Fund' (2009) 22 Rev of Financial Studies 3093.

${ }^{132}$ Luca Enriques and others, 'The Basic Governance Structure: The Interests of Shareholders as a Class' in Reinier Kraakman and others (eds), The Anatomy of Corporate Law, A Comparative and Functional Approach (2nd edn, OUP 2009) 61; Companies Act 2006, s 168.

${ }^{133}$ Brian R Cheffins, 'The Stewardship Code's Achilles' Heel' (2010) 73(6) MLR 1004.

134 Kay Review (n 6) 42.

135 ibid 10, 43.

${ }^{136}$ Kershaw (n 67) 175.

137 ibid.

${ }^{138}$ Catherine Daily, Dan R Dalton and Albert A Cannella Jr, 'Corporate governance: Decades of dialog and data' (2003) 28(3) Academy of Management Rev 371.
} 
on activism indicated little or no effect. ${ }^{139}$ In practice, actions are difficult to coordinate and even completed actions are not impactful.

The efficacy of activism varies dramatically depending on its form, type of investor and the nature of proposals. ${ }^{140}$ No significant impact was felt on short-term performance following remuneration demands, whereas abnormal short-term returns followed demands relating to board composition. ${ }^{141}$ Though these studies were completed before the 'shareholder spring,', 142 they cast doubt on activism's status as a transmission mechanism, as activists' motivations cannot be identified. Interventions for corporate governance purposes, or failed attempts to make short-term gains, are indistinguishable. Further, they highlight the coordination costs involved in orchestrating an action.

While it is recognised there is a need for more long-term focus from investors, this should not result in automatic condemnation of activist strategies that create shareholder value in the short term. Only when strategies destroy more value in the long term should they be subject to criticism and one must accept the unpredictability of business decisions, recognising the fine line between a bad decision and a good decision turned bad. Shareholder 'voice' is not inherently good or bad for a company's prospects, contrary to its portrayal in academic commentary.

Therefore, activism is not considered an effective transmission mechanism in the UK. The market for corporate influence is arguably more developed in the US, 'helped by federal securities and state corporate laws that have greatly inhibited the market for corporate control. ${ }^{143}$ In the UK, the market for corporate control is far more effective as a spectre prompting directors to act myopically, with the market for corporate influence playing a lesser role due to its relative rarity, costs of collective action, ${ }^{144}$ and associated rational apathy.

\footnotetext{
${ }^{139}$ Igor Filatotchev and Oksana Dotsenko, 'Shareholder activism in the UK: types of activists, forms of activism, and their impact on a target's performance' (2013) J of Managements and Governance (published online 24 April 2013) 4.

140 ibid 1.

141 ibid 12.

${ }^{142}$ The 'shareholder spring' refers to investors in several large companies expressing their disapproval of remuneration packages of top executive directors, which was first referred to in media commentary in the spring of 2012. See eg Kate Burgess and Dan McCrum, 'Boards wake up to a shareholder spring', Financial Times (London, 4 May 2012).

${ }_{143}$ Paul Rose and Bernard Sharfman, 'Shareholder Activism as a Corrective Mechanism in Corporate Governance,' (July 2014) Ohio State Public Law Working Paper No 225, fn 4.

144 'Collective action' refers to the behavior of a group working to achieve a common goal. As shareholdings are increasingly dispersed, and shareholders are separated in terms of location with non-UK holders accounting for a majority of the UK equity market, the likelihood of groups of shareholders forming to reach a goal is low as the costs of such activity would outweigh any potential result.
} 
Specific, intensive research is required to reach more than a provisional conclusion on UK activism, as most studies in this area relate to practice in the US.

\section{Executive Remuneration}

The structure of executive remuneration may lead to management replicating the time horizons of the market. If these are short-term oriented, executive remuneration may trigger the transmission of short-termism within the company. Executive remuneration is comprised of a base salary plus both short-term and long-term performance-related elements. ${ }^{145}$ The shortterm element, normally an annual bonus, will often include both corporate and individual performance targets. The longer-term elements might include a share option scheme or another form of long-term incentive plan, often using restricted shares. ${ }^{146}$ Remuneration 'should incentivise the manager to do his utmost to use his skills and experience to maximise the value that can be generated from the company's resources and not to use his power and those resources in ways that benefit himself. ${ }^{147}$ Linking payment to financial results was seen as a remedy for the perceived agency problem between shareholders and executives. ${ }^{148}$

Executive remuneration could be seen as a transmission mechanism as pay is conditioned on, and often delivered as, equity. Therefore, one can expect directors' decisions will take account of expected impact on share price. When remuneration is based on stock market returns, Roe states that management will tend to replicate the time horizons of the market. ${ }^{149}$ This proves problematic if the market has short-term tendencies. This section assesses the formulation of executive remuneration and whether it encourages managerial myopia. It looks at who sets executive remuneration, the reason for high levels of remuneration, and the development of executive remuneration schemes in recent years.

\section{a) The Remuneration Committee}

The Report of the Committee on the Financial Aspects of Corporate Governance recommended the operation of a remuneration committee consisting wholly or mainly of non-executive directors to oversee the process of setting pay. ${ }^{150}$ This served as the impetus for further transformations in the process, ${ }^{151}$ which has culminated in the Remuneration Committee

\footnotetext{
${ }^{145}$ Ruth Bender and Lance Moir, 'Does "Best Practice" in Setting Executive Pay in the UK Encourage "Good" Behaviour?' (2006) $67 \mathrm{~J}$ of Business Ethics 75, 82.

146 ibid.

${ }^{147}$ Kershaw (n 67) 279.

148 Brian Main, 'Executive Pay - a career perspective' (June 2011) Hume Occasional Paper No 89, 2.

149 Roe (n 7) 985.

${ }^{150}$ Committee on the Financial Aspects of Corporate Governance, 'The Financial Aspects of Corporate Governance' (Professional Publishing Ltd 1992) (Cadbury); Corporate Governance Code D.2.2.

${ }^{151}$ Corporate Governance Code D.2.2; Richard Greenbury, 'Directors' Remuneration: Report of a study group chaired by Sir Richard Greenbury’ (Confederation of British Industry 1996) (Greenbury); Derek Higgs, 'Review
} 
consisting of two or three independent non-executive directors and the chairman, if he was independent upon appointment. ${ }^{152}$ The remuneration committee finds itself trapped in an institutional isomorphism of practice ${ }^{153}$ whereby the practice of other companies becomes a guide to what should be done in their company. Increases in disclosure allow remuneration committees to look around to see what other committees are doing. ${ }^{154}$ They often err on the side of generosity ${ }^{155}$ therefore, as they do not want to risk the disruption and expense that would ensue if their frugality led to executive turnover, demoralisation or distraction. ${ }^{156}$

\section{b) Share Options and the Use of 'Long Term Incentive Plans'}

Reform has occurred in the structure of executive remuneration in an attempt to align it more closely with the long-term performance of the company. Previously, the granting of share options signalled a revolution in how executives were paid. Options linked payment to financial results, incentivising the executive 'to work at 100 [percent] of his capacity.' ${ }^{157}$ The identification of the senior managerial class with the goal of share price maximisation became 'ever more complete. ${ }^{158}$ Stock options fell into disfavour however, as managers were free to exercise them when stock prices increased but could sit tight when they decreased. ${ }^{159}$ Therefore, directors were not negatively impacted if their strategies were unsuccessful in the long run. Greenbury ${ }^{160}$ encouraged a move away from options and toward other long-term incentive plans (LTIPs). The implosion of the 'dot com bubble' added momentum to this drive towards performance share plans. ${ }^{161}$ The typical remuneration schemes then in use, particularly stock options, became viewed as 'rewards for failure.' 162

Tying share performance to reward is appealing given the information asymmetry and confounding factors that beset any analysis of 'true' executive value addition. ${ }^{163}$ However,

of the Role and Effectiveness of Non-executive Directors' (Department for Business, Enterprise and Regulatory Reform 2003).

${ }^{152}$ Corporate Governance Code D.2.1.

153 Paul DiMaggio and Walter Powell, 'The iron cage revisited: institutional isomorphism and collective rationality in organizational fields' (1983) 48 American Sociological Rev 147.

${ }^{154}$ Main (n 148) 8.

155 ibid 9.

156 ibid.

157 Kershaw (n 67) 281.

${ }^{158}$ Deakin (n 109) 14.

${ }^{159}$ Lynne Dallas, 'Short-Termism, the Financial Crisis, and Corporate Governance,' (2012) 37(2) J Corp L 265 , 357.

${ }^{160}$ Greenbury (n 151) para 6.31.

${ }^{161}$ Main (n 148) 6.

${ }^{162}$ John Kay, 'The Kay Review of UK Equity Markets and Long-Term Decision Making' Interim Report, (BIS 2012) para 3.39.

${ }^{163}$ Main (n 148) 5; Michael C Jensen and Kevin J Murphy, 'Performance pay and top-management incentives' (1990) $98 \mathrm{~J}$ of Political Economy 225. 


\section{Contextualising Short-Termism: Does the Corporate Legal Landscape Facilitate Managerial Myopia?}

executives whose shares are overvalued have an incentive to defend that unrealistic price, which can lead to fraudulent behaviour. Remuneration based in any way on share price exacerbates this. ${ }^{164}$ Ideal pay incentives reflect both upside potential and downside risk. The incentive that most closely aligns the interests of executives and shareholders is management holding shares. Yet, since the effects of important investment decisions are felt over longer time horizons than executive tenures, 'shares should be held up to or beyond the date at which the executive leaves office.' 165

These considerations led to the increased use of LTIPs and by 2005, the use of performance share plans in the FTSE 100 was at 84 percent. ${ }^{166}$ A commonly used performance measure for LTIPs is total shareholder return. ${ }^{167}$ This measures return to investors over a fixed (commonly three-year) period and compares it to returns from comparable companies, or an index. ${ }^{168}$ If a company earns lower than the median, the LTIP shares will not vest and any vesting is in proportion to the company's position on a ranking, with full vesting for upper quartile performance. ${ }^{169}$ Despite these innovations and their accompanying adoption, doubts remain on the investor side over whether, for instance, three-year mechanisms are sufficiently long term to incentivise directors to focus on long-term value creation rather than short-term increases in share price. Meanwhile, managers may protest that total shareholder return is not truly reflective of executive behaviour as companies are 'at the mercy of market sentiment, particularly if it benchmarks against an index [...] and is in an out-of-favour sector. ${ }^{170}$ This could be perceived as an instance where the dissatisfaction of both sides signals a fair compromise, albeit one that this author believes should be struck further in investors' favour, as will be discussed in the Regulatory Recommendations section of this paper.

\section{c) A Flashpoint for Shareholder Concerns}

In 2012, the 'shareholder spring' resulted in investors expressing their disapproval regarding executive pay in the exercise of their corporate rights, resulting in the dismissal of several CEOs. ${ }^{171}$ A year later, legislation requiring a binding shareholder vote on proposed director

\footnotetext{
${ }^{164}$ Michael C Jensen, 'The Agency Costs of Overvalued Equity and the Current State of Corporate Finance,' (2004) 10(4) Eur Fin Management 549; Bender and Moir (n 145) 84.

165 Kay Interim (n 162) para 3.39.

166 Robert Booker and Vicky Wright, (2006) 'Relative shareholder return - the best measure of executive performance?' What if? Perspective (Watson Wyatt).

${ }_{167}$ Bender and Moir (n 145) 83.

168 ibid.

169 ibid.

170 ibid.

${ }^{171}$ Kate Burgess 'How shareholder activists can put UK companies in a bind,' Financial Times (London, 13 January 2014).
} 
pay was enacted. ${ }^{172}$ The addition of a binding vote does not neutralise the possible effect of executive remuneration as a transmission mechanism. It retains the status quo, leaving remuneration committees to create remuneration schemes shareholders will approve of, hence rewarding directors for maximising shareholder value within these voting investors time horizons. The result is that it mimics any short-termism present in the markets. Currently, therefore, executive remuneration may be seen as transmitting short-termism and the addition of a binding vote on remuneration is unlikely to have a substantial impact on this fact. ${ }^{173}$ The preferred approach would be to target the way in which long-term incentives are delivered so as to ensure that they are genuinely long term, and deter myopic behaviour by managers. ${ }^{174}$

\section{Managerial perceptions of short-termism}

Professor John Kay 'excoriated public company short-termism and sought means to reduce that short-termism.' ${ }^{175}$ The Aspen Institute posited 'short-term thinking had become endemic in business and investment, and it posed a grave threat to the US economy.' ${ }^{176}$ The 'motif' ${ }^{177}$ is that a short-term focus 'has systematically robbed the economy of the patient capital it needs to produce sustained and vigorous economic growth.' ${ }^{178}$ Investors, asset managers and executives are seen as focused on short-term and the general view is that executives ignoring this find themselves 'kicked to the street by impatient investors.' 179

However, let us assume shareholders take a long-term view but are not perceived to do so by managers. ${ }^{180}$ If the argument that short-termism exists in the UK market is unconvincing, managerial perceptions of short-termism become significant. Behavioural biases play a role in encouraging short-termism. ${ }^{181}$ By analysing questionnaire responses of boards of directors of over 200 listed companies, research conducted over 15 years ago concluded that if managers perceive the market will evaluate the company using short-term criteria, they will behave myopically. ${ }^{182}$ Stein argues that even where capital markets are efficient, ie even when

\footnotetext{
172 Enterprise and Regulatory Reform Act 2013.

${ }^{173}$ Ian Gregory-Smith and Brian Main, 'Response to The Kay Review of UK Equity markets and Long-Term Decision Making' (2012) 6-7

〈http://homepages.ed.ac.uk/mainbg/Files/Kayvotes_response_FINAL_27_04_2012.pdf> accessed 23 January 2016.

174 ibid.

175 Roe (n 7) 984.

${ }^{176}$ Samuelson and Stout (n 10) A13.

177 Roe (n 7) 984.

178 Steven Pearlstein, 'Wall Street's Mania for Short-Term Results Hurts Economy' Washington Post (Washington DC, 11 September 2009) A20.

${ }^{179}$ Nocera (n 10) A21.

${ }^{180}$ Marston and Craven (n 3) 237.

${ }^{181}$ Dallas (n 159) 269.

${ }^{182}$ Demirag (n 19) 196.
} 
managers know they cannot systematically 'fool' the market, managers will be acting myopically. ${ }^{183}$ Referring to the prisoners' dilemma, he advocates that all parties, in this case managers, try to cheat because they believe other managers are doing the same. ${ }^{184}$

For perceptions to induce short-termism, management's investment horizon would have to be shorter than that of the average shareholder or they would have to misread the market's preferences, for example by overestimating the extent or intensity of shareholder short-termism. Given the motif of short-termism as a systemic issue, possible overestimation of the intensity of short-termism by directors is not that far-fetched a proposition. These studies demonstrate the value of perceptions as a theoretical construct ${ }^{185}$ in exploring short-term behaviour in companies. Perceptions of short-termism may be sufficient to transmit shorttermism to the corporate decision-making body whether or not short-termism actually exists in the market.

\section{THE SHORT-TERMIST ARGUMENT AS PROXY FOR MANAGERIALISM}

Managerialism is the belief in or reliance on the use of professional managers in directing a company. This ideology favours greater deference to the board of directors and less interference from shareholders generally. Its adherents have not been slow to seize on the increasingly fashionable issue of short-termism as further evidence that management knows best and shareholders are often a malign influence on decision-making. The managerialist analysis of short-termism posits that shareholders harbour short-termist tendencies due to their financial self-interest, whereas managers are more naturally aligned with sustainable company growth and long-term value creation.

However, an established body of opinion shaped contemporary views on the roles of management and shareholders, with Berle arguing that corporations are only accountable to their shareholders. ${ }^{186}$ This shareholder-centric approach has not gone unchallenged though, and recasting shareholders as only one of several types of stakeholder in a company naturally demands that their dominance be curtailed and management assume a role of increased importance and independence from shareholder demands. Thus, some of the concerns

\footnotetext{
183 ibid; Stein (n 8).

${ }^{184}$ Stein (n 8) 656.

185 Demirag (n 19) 208.

186 See Adolf A Berle, 'Corporate Powers as Powers in Trust' (1931) 44 (7) Harvard L Rev 1049; E Merrick Dodd, 'For Whom are Corporate Managers Trustees?' (1932) 45(7) Harvard L Rev 114; John CC Macintosh, 'The Issues, Effects and Consequences of the Berle-Dodd Debate, 1931-2' (1999) 24(2) Accounting, Organizations and Society 139, 139.
} 
expressed regarding short-termism may be seen to be exploiting a topical concern to arrive at a predetermined policy outcome.

Insulation of the board from the shareholders, rather than reforming and detoxifying the feedback mechanisms between them, is the prescription for which managerialists reflexively reach. Thus, takeover protection is a prominent policy prescription 'induced by those who see stock market induced short-termism as a serious problem. ${ }^{187}$ Martin Lipton attacked financial market short-termism by proposing the empowerment of managers to defeat hostile takeovers in the US in his seminal 1979 article 'Takeover Bids in the Target's Boardroom. ${ }^{\text {' }} 88$ Takeover regulation took a very different form in the UK, where this justification did not result in empowerment. 'Diametrically opposed choices' were therefore made by the two jurisdictions. ${ }^{189}$

In the managerialist camp, Bainbridge has endorsed director primacy, ${ }^{190}$ Blair and Stout espoused the 'team production' model, which conceives of the board as a mediating hierarch, ${ }^{191}$ and Elhauge argued that managers must have 'discretion to sacrifice profits in the public interest. ${ }^{192}$ As a treatment for short-termism, proponents of greater board autonomy claim it fosters long-term sensible behaviour. These arguments pivot on the assertion that shareholders are best served by managers with discretion and autonomy. Shareholders are perceived as being poorly informed, prone to disagreements on corporate strategy and disruptive to the board if given too much authority to affect decision-making directly. ${ }^{193}$ With greater insulation, management are granted the opportunity to take a long-term view of company's commercial needs rather than being pressured to adopt a short-term strategy to maximise shareholder value. ${ }^{194}$

However, there is an element of opportunism in how managerialists have attached themselves to the current corporate governance debate on short-termism to advance a view that predates it. In the UK, greater board autonomy could enable the board to protect the company from takeovers. Zhao, Chen, Zhang, and Davis state that this reduces managerial pressure to

\footnotetext{
${ }^{187}$ Roe (n 7) 994.

${ }^{188}$ Lipton (n 103).

189 Armour and Skeel (n 26) 1737; Paul Davies and Klaus Hopt, 'Control Transactions' in Reinier Kraakman and others (eds) The Anatomy of Corporate Law: A Comparative and Functional Approach (1st edn, OUP 2004) 157, 164.

190 Stephen M Bainbridge, 'Director Primacy and Shareholder Disempowerment' (2006) 119 Harvard L Rev 1735. ${ }^{191}$ Margaret Blair and Lynn Stout, 'A Team Production Theory of Corporate Law' (1999) 85(2) Virginia L Rev 247, 276-287.

192 Einer Elhauge, 'Sacrificing Corporate Profit in the Public Interest' (2005) 80 NYU L Rev 733.

193 Bainbridge (n 191) 1745-1749.

${ }^{194}$ For a sophisticated argument on this point, see Martin Lipton and Steven Rosenblum, 'A new system of corporate governance: The quinquennial election of directors’ (1991) 58 U of Chicago L Rev 187.
} 
resort to short-term behaviour, ${ }^{195}$ but generally, it does not appear the insulation of boards leads to higher R\&D as one would expect if this argument is correct. ${ }^{196}$ Therefore, there is scant evidence to indicate that increasing board autonomy leads to long-term investment and development, as managerialists claim. Short-termism should not be used as a proxy for managerialism; ${ }^{197}$ the managerial approach is not bolstered by reliance on short-termism and any call for greater board autonomy must stand or fall on its own merits. ${ }^{198}$

\section{E. REGULATORY RECOMMENDATIONS}

As the earlier sections have identified, there are transmission mechanisms in UK company law and takeover regulation that lead to short-term tendencies in the market and affect the management of companies. As a consequence, managers focus on short-term results to avoid the company becoming a takeover target, to earn higher compensation, and to prevent their removal from the board. Thus, the recommendations proposed are aimed at corporate governance reform. These are in line with this ministerial statement of Stephen Byers, then Secretary of State for Trade and Industry:

The key to shaping the market in ways that achieve our twin objectives of efficiency and social justice lie in the framework of rules within which companies do business and make a profit. So company law and corporate governance are at the heart of our debate about the kind of society we want and the nature of our economy. ${ }^{199}$

It is accepted that regulation is a "negative approach based on restrictions, ${ }^{200}$ which market participants will attempt to circumvent, and 'no single reform will provide the solution. ${ }^{\text {,201 }}$ Regulation, though imperfect, is, however, necessary. Breaking the transmission mechanism from market to corporate decision-making bodies, or perhaps more accurately, from perceptions to decisions, is essential to lessen the adverse effects of short-termism and restrict its inroad into boardroom decision-making. Further realignment of incentives and encouraging effective engagement between shareholders and executives could loosen short-

\footnotetext{
195 Zhao and others (n 120).

${ }^{196}$ Ravi Jain and Sonia Wasan ‘Adoption of Antitakeover Legislation and R\&D Expenditure' (2009) 6 Investment Management and Fin Innovations 63; Mark Johnson and Ramesh Rao 'The Impact of Antitakeover Amendments on Corporate Financial Performance' (1997) 32 Fin R 659.

${ }_{197}$ Roe (n 7) 1003.

198 ibid 1004.

199 Stephen Byers, Speech to TUC/IPPR seminar on corporate governance (London 7 June 2000) $<$ http://collections.europarchive.org/tna/20010301100355/http://dti.gov.uk/ministers/speeches/byers070600.htm $1>$ accessed 23 January 2016.

${ }^{2} 00$ Woolley (n 2) 123.

${ }^{201}$ Kay Review (n 6) 9.
} 
termism's grip. The following recommendations focus on the transmission mechanisms identified earlier as effective: takeovers, shareholder activism, and executive remuneration.

\section{Takeovers}

Without a change to the Code, takeovers will continue to act as a transmission mechanism. Removing the non-frustration principle contained in Rule 21 would enable ex ante shareholder authorisation of certain defensive actions. ${ }^{202}$ The possibility of change is acknowledged, but UK and EU corporate law limit the availability of takeover defences that 'provide management with considerable discretion to resist if not unequivocally prohibit a bid. ${ }^{203}$ Removal of Rule 21 would remove a prohibition of shareholders' contractual expression, ${ }^{204}$ but with 'trivial impact on activity levels in the market for corporate control. ${ }^{205}$ If approval is not readily given, short-termist views will still be transmitted into corporate decision-making. Hostile takeovers are seen as a transmission mechanism, and an obvious solution does not present itself.

\section{Shareholder Activism}

Currently, shareholder activism is not perceived to be acting as a transmission mechanism. There are many championing the rights of shareholders to utilise their 'voice' in corporate governance matters, with the Kay Review emphasising the importance of the quality of engagement by investors and promoting a broadening of the existing concept of stewardship. ${ }^{206}$ A key test for stewardship will be the impact of increasing shareholder power over remuneration since $2013,{ }^{207}$ as it is feared fragmentation of shareholding will prevent this making a real tangible impact.

Further, the Enterprise and Regulatory Reform Act 2013 gives shareholders a legally binding vote on future pay policy once every three years, backed by an advisory (ie nonbinding) annual shareholder vote. Thus, although shareholders voted against the almost $£ 14 \mathrm{~m}$ remuneration package for BP chief executive Bob Dudley, this vote was non-binding as 2016 was a year where such shareholder votes were advisory. Mr Dudley's remuneration was not changed. $^{208}$

\footnotetext{
${ }^{202}$ David Kershaw, 'The Illusion of Importance: Reconsidering the UK's Takeover Defence Prohibition' (2007) 56(2) ICLQ 267, 271; Carsten Gerner-Beuerle, David Kershaw and Matteo Solinas, 'Is the Board Neutrality Rule Trivial? Amnesia about Corporate Law in European Takeover Regulation' (2011) 22 Eur Business L Rev 559, $570,582$.

${ }^{203}$ Kershaw Illusion (n 202) 269.

204 ibid 298.

${ }^{205}$ Gerner-Beuerle, Kershaw and Solinas (n 202) 582.

${ }^{206}$ Kay (n 6) 44: In this context, 'stewardship' refers to engagement between shareholders or asset managers and company boards to help improve long-term risk-adjusted returns to shareholders.

${ }^{207}$ Enterprise and Regulatory Reform Act 2013 (n 172).

${ }^{208}$ Kiran Stacey, David Oakley, Stephen Foley 'BP Investors revolt over chief Bob Dudley’s 20\% pay rise,' Financial Times (London, 14 April 2016).
} 
While Theresa May has recently stated there should be a binding vote on executive remuneration, ${ }^{209}$ this paper recommends that a cautious approach must be taken if reform is proposed on shareholder activism. Shareholders exhibit biases and any recommendation encouraging a stronger shareholder 'voice' must be tempered by the recognition that this could enable activism to become a transmission mechanism for short-termism. This possibility must be afforded due consideration, recognising that '[s]hareholder engagement is neither good nor bad in itself: it is the character and quality of that engagement that matters. ${ }^{210}$

\section{Executive Remuneration}

The issue with executive remuneration is not that directors are paid too much, but that they are

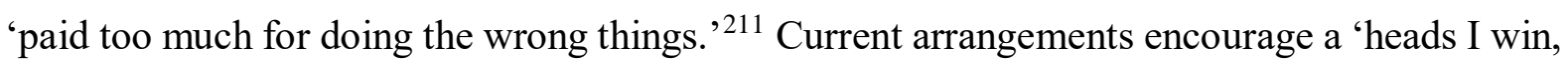
tails you lose' perspective on decision-making. ${ }^{212}$ The structure of remuneration should be altered to promote long-term value and reward directors for achieving this. To do this, Main proposes 'Career Shares. ${ }^{213}$ Career Shares would require the director to retain the shares concerned until the end of a period following exit from the company. Commentators have recommended three, ${ }^{214}$ four ${ }^{215}$ and ten ${ }^{216}$ years as potential retention periods. As final remuneration would depend on how the company is performing years after the director's exit, strategies put in place during their tenure need to continue to deliver. The reasoning behind Career Shares is that ' $[\mathrm{m}]$ anagers with longer horizons will [...] be less likely to engage in imprudent $[\ldots]$ strategies or short-term earnings manipulation when the ability to exit before the problem comes to light is greatly diminished.' ${ }^{217}$

Potential trade-offs associated with this recommendation include a higher turnover of executives or early departure if they believe the share price has peaked, to capture some of the value. $^{218}$ Though labour mobility at this level is often overstated, this possibility cannot be ruled out. ${ }^{219}$ The executive's successor must also continue to perform well or the reward will

\footnotetext{
209 Jim Pickard 'Theresa May Vows Corporate Crackdown On "Privileged Few"' Financial Times (London, 10 July 2016).

210 Kay (n 6) 20.

${ }^{211}$ Samuelson and Stout (n 10) A13.

212 Gregory-Smith and Main (n 173) 1.

213 Main (n 148) 10.

${ }^{214}$ Rappaport (n 7) 73.

215 Sanjai Bhagat and Roberta Romano, 'Reforming Executive Compensation: Focusing and Committing to the Long-Term' (2009) 26 Yale J on Regulation 359.

${ }^{216}$ Lucian Bebchuk and Jesse Fried, 'Paying for the long-term performance' (2010) 158 U of Pennsylvania L Rev 1915.

${ }^{217}$ Bhagat and Romano (n 215) 465-66.

${ }^{218}$ Sean O'Hare, 'The Kay Review - PwC comments' (23 July 2012)

<http://pwc.blogs.com/press_room/2012/07/the-kay-review-pwc-comments.html > accessed 23 January 2016.

${ }^{219}$ Main (n 148) 9.
} 
decrease. A period of five years is suggested, as it may strike a balance by incentivising a longterm focus without rendering the director at the mercy of their successor's achievements. When evaluating these trade-offs, one must bear in mind that LTIPs, Career Shares, and similar schemes represent only a portion of director's pay. ${ }^{220}$ Therefore, it seems unlikely the recommendation will have a drastic impact on executive turnover. On balance, it is argued Career Shares encourage long-term thinking without rendering executive positions financially unappealing. 221

The composition of the remuneration committee also merits examination. If nonexecutive members of the committee are executive directors of other companies and will indirectly benefit from an increased market standard, ${ }^{222}$ this may lead to increasing remuneration. Preventing these members from holding the position of committee chair could alleviate undue pressure to increase remuneration. ${ }^{223}$ To reward directors properly on performance increasing long-term value, Career Shares remedy the short-term aspect of performance-based remuneration. In addition, neutrality of the remuneration committee, at least for the position of chair, will prevent excessive generosity as a result of isomorphism of practice combined with indirect self-interest.

\section{F. CONCLUSION}

The short-termist argument recognises the importance of maximising long-term value and, from an economic perspective, the argument incorporates market imperfections and the reality that we have to strive for efficiency. It values patience, perseverance, and faith in future rewards, ${ }^{224}$ and therefore it came as no surprise that the argument caught the imagination of the corporate legal world and has become a common feature in media and academic commentary. This paper has examined short-termism from a UK perspective, finding evidence of shorttermism in market characteristics like decreasing holding periods, the knowledge and nature of investors. The available evidence is reflective of a harmful short-term focus, which would benefit from action by legislators and regulators. After analysing the perceived weaknesses of the short-termist argument, including arguments that shortening of the average holding period is due to HFT, and that the market displays excessive long-termism, this author finds that these are not sufficiently convincing to alter that conclusion. Further, this paper considers that

\footnotetext{
220 ibid 12.

221 ibid.

222 Kershaw (n 67) 304.

223 ibid.

${ }^{224}$ Pickens (n 11) 76.
} 


\section{Contextualising Short-Termism: Does the Corporate Legal Landscape Facilitate Managerial Myopia?}

perceptions of short-termism alone can lead to managerial myopia. Managers might take actions to increase current earnings at the expense of long-term growth, due to a belief that short-termism pervades the market.

In a letter to Berkshire Hathaway shareholders, Warren Buffett wrote, 'when we own portions of outstanding businesses with outstanding managements, our favourite holding period is forever.' 225 This serves as a reminder that effective engagement between managements and investors can lead to long-term success. However, if mechanisms transmit a short-term focus from the market to the corporate decision-making body, executives are not focused on the long-term: they are behaving myopically. The consequences of short-termism in the market are determined by the corporate legal and regulatory landscape. After examining the impact of hostile takeovers, shareholder activism and executive remuneration, the primary conclusion of this paper is that short-termism in public firms is something that should affect regulatory and legislative proposals in the UK. There are sufficient mechanisms transmitting short-termism present in the markets to corporate decision-making to render the phenomenon worthy of regulatory attention. In particular, hostile takeovers and executive remuneration are particularly effective transmission mechanisms, with shareholder activism's impact circumscribed by the costs of collective action and rational apathy.

The regulatory proposals contained in this paper demonstrate a path reform should take, including an endorsement of Main's Career Shares and reform of the composition of remuneration committees. Breaking the transmission mechanism is key to preventing shorttermism creeping its way further into corporate decision-making. As the transmission mechanisms are multi-faceted, reforms involving many stakeholders are necessary. This paper therefore offers solutions to combat managerial myopia and re-focus executive attention to long-term value creation.

225 Warren Buffett, Chairman's Letter to Shareholders of Berkshire Hathaway, (28 February 1989) <http://www.berkshirehathaway.com/letters/1988.html> accessed 23 January 2016. 